A.

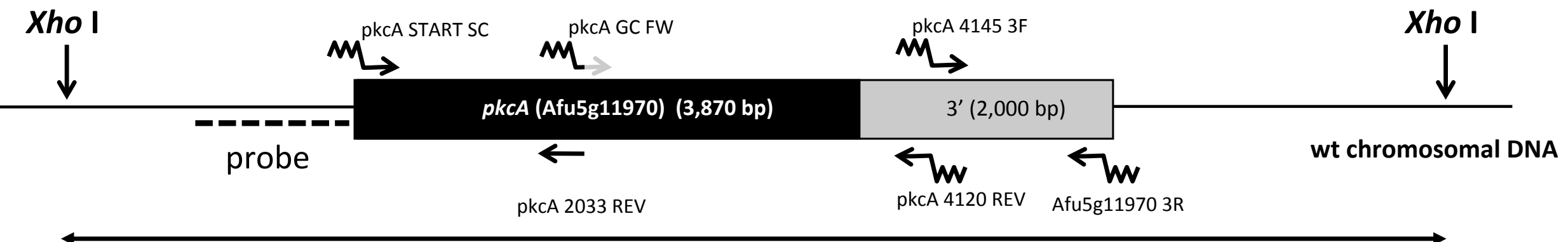

\title{
$9.2 \mathrm{~kb}$
}
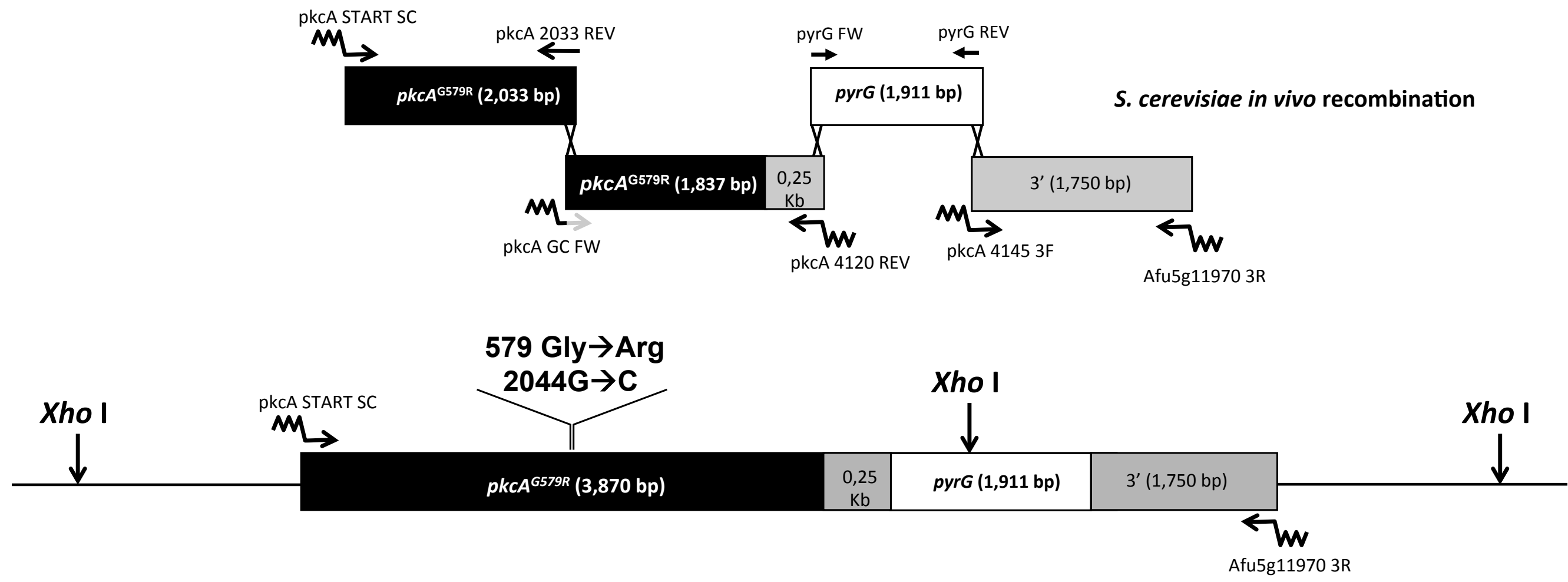

$5.1 \mathrm{~kb}$

$p k c A^{\text {G579R }}$ chromosomal DNA 
B.

wt pkcA ${ }^{\mathrm{G579R}}$

$9.2 \mathrm{~kb}$

$5.1 \mathrm{~kb}$

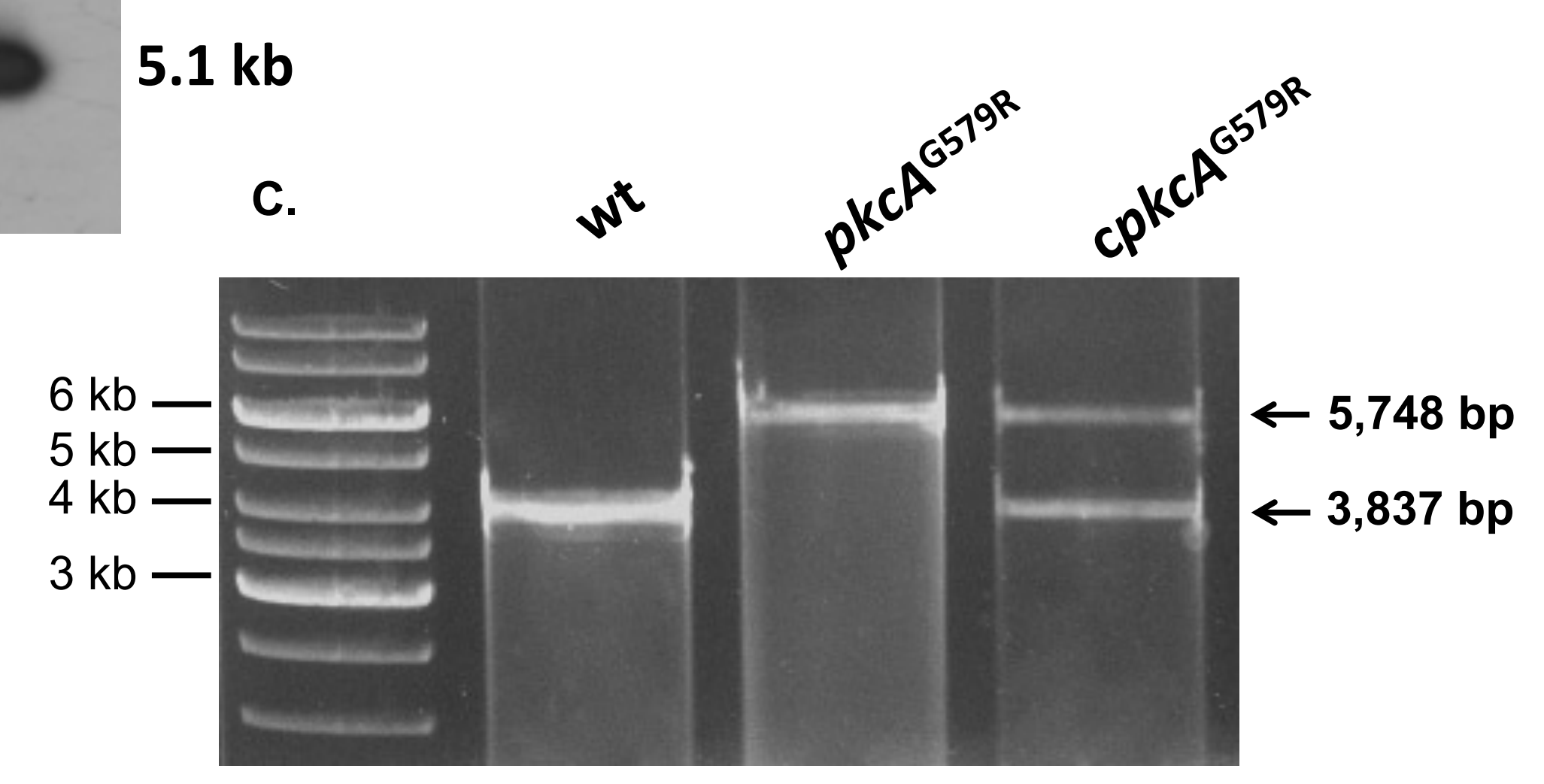

